Article

\title{
The Paleogene Gosau Group Slope Basins of the Incipient Eastern Alpine Orogenic Wedge: A Case Study at the Gams Basin (Austria)
}

\author{
Veronika Koukal $^{1, *(\mathbb{D}}$, Michael Wagreich ${ }^{1}\left(\mathbb{D}\right.$, Mădălina-Elena Kallanxhi ${ }^{2,3}\left(\mathbb{D}\right.$ and Wolfgang Knierzinger ${ }^{1}$ \\ 1 Department of Geology, Faculty of Earth Sciences, Geography and Astronomy, University of Vienna, \\ 1090 Vienna, Austria; michael.wagreich@univie.ac.at (M.W.); wolfgang.knierzinger@univie.ac.at (W.K.) \\ 2 Department of Geology, Faculty of Geology and Biology, Babes-Bolyai University, \\ 400084 Cluj-Napoca, Romania; madalina_kallanxhi@yahoo.com \\ 3 Albanian Geological Survey, 1007 Tiranë, Albania \\ * Correspondence: veronika.koukal@univie.ac.at
}

Citation: Koukal, V.; Wagreich, M.; Kallanxhi, M.-E.; Knierzinger, W. The Paleogene Gosau Group Slope Basins of the Incipient Eastern Alpine Orogenic Wedge: A Case Study at the Gams Basin (Austria). Minerals 2022, 12, 178. https://doi.org/10.3390/ $\min 12020178$

Academic Editor: Luca Aldega

Received: 12 November 2021

Accepted: 26 January 2022

Published: 29 January 2022

Publisher's Note: MDPI stays neutral with regard to jurisdictional claims in published maps and institutional affiliations.

Copyright: (C) 2022 by the authors. Licensee MDPI, Basel, Switzerland. This article is an open access article distributed under the terms and conditions of the Creative Commons Attribution (CC BY) license (https:// creativecommons.org/licenses/by/ $4.0 /)$.

\begin{abstract}
This study investigates the Paleogene deep-water depositional system of the Gosau Group at Gams, Styria (Austria). The examined sections of the Danian to the Ypresian age (NP1-NP12) comprise sediments of the Nierental and Zwieselalm Formations. Four deep-water clastic facies assemblages were encountered: (1) pelagic marls with thin turbidites, (2) carbonate-rich turbidites, (3) carbonate-poor turbidites, and (4) marl-bearing turbidites; slump beds and mass flow deposits are common features in all facies assemblages. Based on heavy mineral, thin section, microprobe, and paleoflow analyses, provenance was from the surrounding Northern Calcareous Alps (NCA) rocks and exhuming metamorphic Upper Austroalpine units to the south. In addition, biogenic calcareous material was delivered by adjacent contemporaneous shelf zones. The sedimentary depocenter was situated at the slope of the incipient Alpine orogenic wedge, in frontal parts of the NCA, facing the subducting Penninic Ocean/Alpine Tethys. The evolution of the Gams Basin was connected to the eoalpine and mesoalpine orogeny and the adjunctive transpressional setting. The Gams deep-water depositional system is interpreted as an aggrading or prograding submarine fan, deposited into a small confined slope basin, positioned along an active continental margin, bound and influenced by (strike-slip) faults, related to crustal shortening. The development of the Gams slope basin and its infilling sequences was mainly dominated by tectonism and sediment supply, rather than by eustatic sea-level fluctuations. The basin was cut off during the Eocene due to renewed orogeny. A Quaternary analogue for the Upper Cretaceous to Paleogene basin setting of the Gams area is represented by the Santa Monica Basin in the California Continental Borderland.
\end{abstract}

Keywords: Eastern Alps; Paleogene; slope basin; Upper Gosau Group; turbidites

\section{Introduction}

Since the 1960s, various depositional models of turbidite and other deep-water massflow systems have been proposed [1-15]. Fossil clastic deep-water systems are often only partly preserved and exposed, and thus provide significant research challenges, such as questions on the original depositional settings and the types of basin and basin fills. Reconstruction of deep-water basin fills and their stratal geometries has become also a primary target for deep-water hydrocarbon exploration [16-18].

The siliciclastic and mixed siliciclastic-carbonate deep-water succession of the Upper Gosau Subgroup of Gams (Styria, Austria, Upper Cretaceous-Eocene) represents deepwater, mainly turbiditic deposition [19] within a formerly tectonically active part of the Northern Calcareous Alps (NCA), Eastern Alps (Figure 1). Late early to Late Cretaceous eoalpine thrusting within the incipient Alpine orogenic wedge is linked to the development of several Gosau basins due to subduction tectonic erosion and subsidence at the front of 
the Austroalpine microplate [20-22]. In general, the Gosau Group records a widespread former sedimentary cover on top of the NCA, deposited in the northwestern Tethys palaeogeographic realm. These Gosau basins form erosional remnants today, exposed throughout various locations in Austria and southern Germany [23]. Research on the individual Austrian Gosau basins and correlating them helps to attain a better understanding of the overall development of the Alpine orogenic wedge and the Upper Austroalpine units, during the Cretaceous and early Paleogene, connected to eoalpine and mesoalpine orogenic events.

The Gosau Group of Gams rests unconformably upon Permian-Jurassic, mainly carbonate strata of Tirolian NCA nappes and preserved the transition from terrestrial and shallow-marine strata (Turonian-Campanian) of the Lower Gosau Subgroup to the deepwater marls, marly limestones, shales, sandstones, and deep-water mass-flow deposits of the Upper Gosau Subgroup (Campanian-Eocene) within the sedimentary record [24]. Detailed stratigraphic investigations started from the 1960s onwards [22,24-29], including multiple sections featuring the Cretaceous/Paleogene $(\mathrm{K} / \mathrm{Pg})$ boundary in the Nierental Fm and the Paleocene/Eocene (P/E) boundary of the Zwieselalm Fm [30-35] (Figures 1 and 2). The lithostratigraphic definition of the Nierental Fm is based on the stratotype section of the Lattengebirge at Berchtesgaden (Bavaria, Germany) [36]. Bright gray to dark gray and red calcareous marlstones to marly pelagic limestones are dominant, though minor claystones and marly claystones are also present. Turbiditic sandstone beds are infrequent, usually between 0 and 20\% of the stratotype succession [36]. The Nierental Fm at Gams closely follows this description [37]. The Zwieselalm Fm, with its type locality at Gosau, Upper Austria [23], is characterized by turbidite beds of variable thickness and carbonate content, fine-grained breccia beds, dark gray turbiditic shales, and brown to gray marls and marlstones. Mass-flow deposits, slumps, and olistostromes occur significantly more frequently there than within the Nierental Fm, as is also reported from the Gams Basin [22,24].

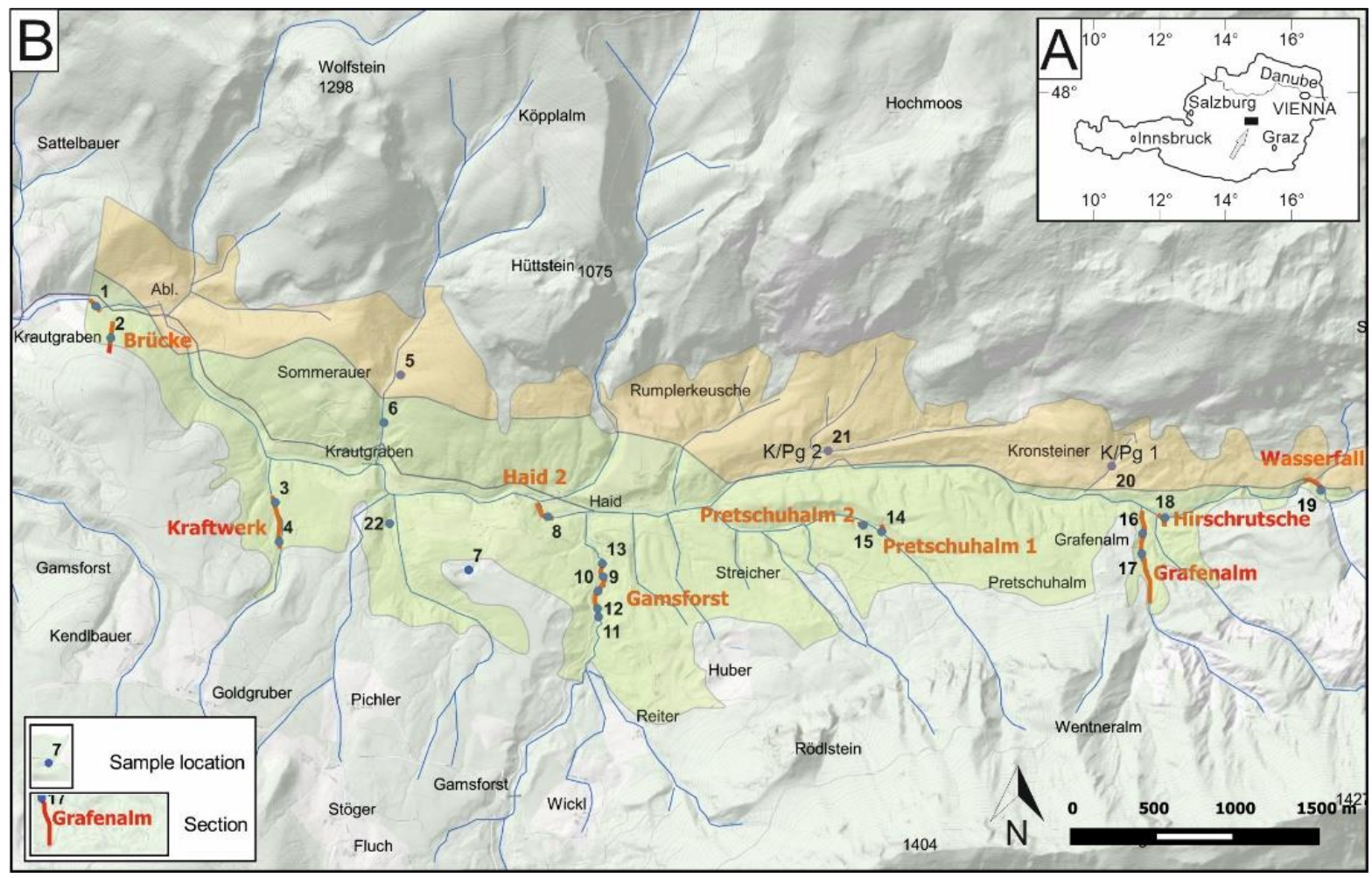

Figure 1. (A) Inset map of Austria and the location of Gams. (B) Detailed map of investigated sections and sample spots, including the Nierental Fm (yellow) and the Zwieselalm Fm (green). K/Pg 1 and $\mathrm{K} / \mathrm{Pg} 2$ mark the Cretaceous/Paleogene boundary sites. The map was created using data from www.basemap.at (accessed on 8 April 2017), OGD license [38]. 


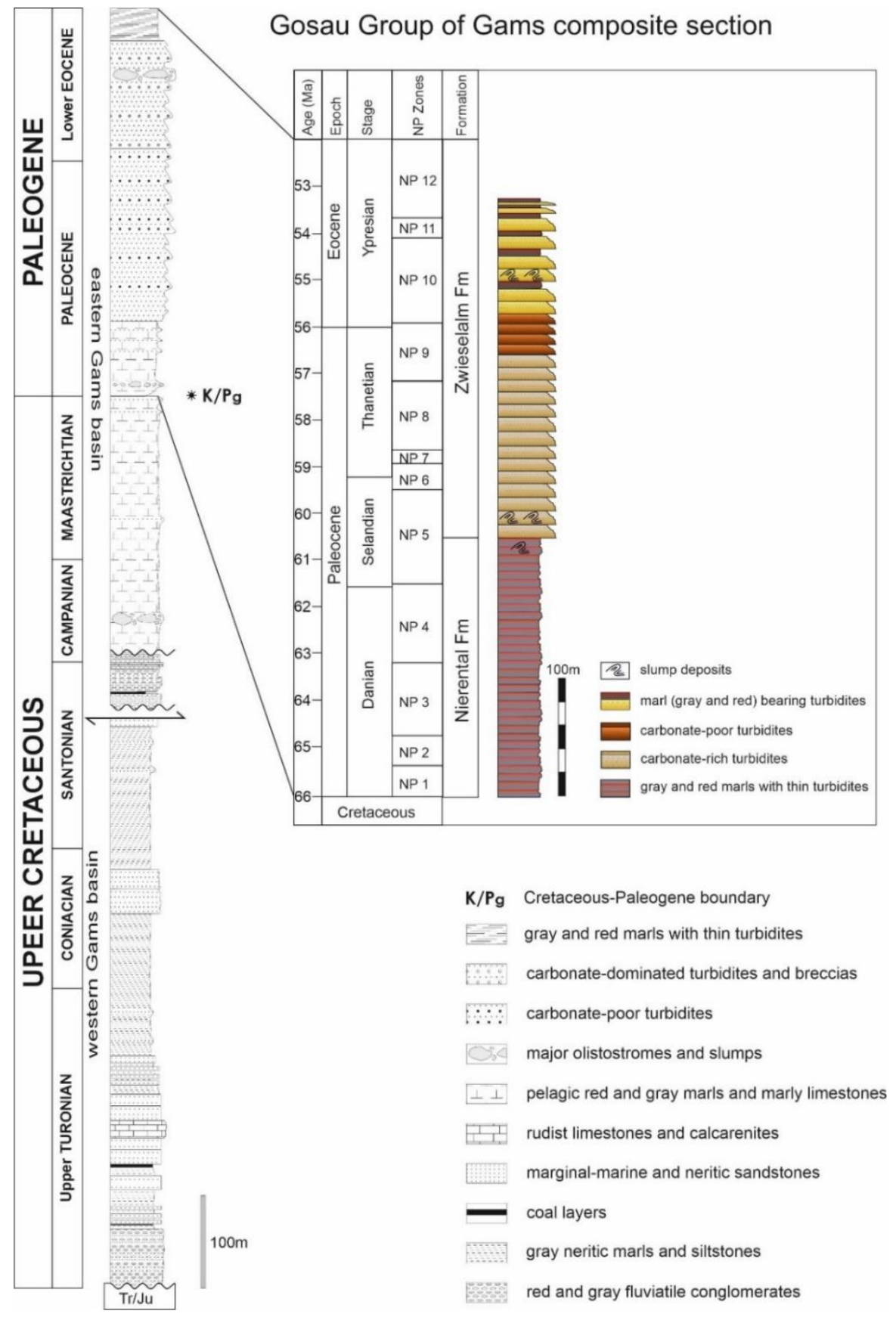

Figure 2. Schematic log of the Gams Gosau Basin fill and (inset) composite log of the Upper Gosau Group of Gams in the eastern Gams Basin with the associated facies assemblages. Strongly modified from [28].

The main focus of this study is to gain a better understanding of sedimentology, facies, stratigraphy, provenance, and the depositional history and processes of the Paleogene (Danian-Ypresian) Nierental Fm and Zwieselalm Fm of the fossilized Gams Basin (Figure 1). The working hypothesis is that the deep-water system of the Upper Gosau Subgroup comprises part of a large NCA clastic slope deep-water depositional system in a tectonically active margin/orogenic wedge setting. The Gams Basin is thus compared with other slope basin settings [6,7,14-16,39-43] and their evolution in time. The Quaternary California Continental Borderland is used as a sedimentary and structural analogue for the Paleogene sedimentation in the Gams Basin and serves as a model for other Gosau basins. 


\section{Materials and Methods}

Detailed field bed-by-bed measurements and field sedimentology evaluation of grain size and sedimentary structures of 8 sections (Brücke, Gamsforst, Grafenalm, Haid 2, Hirschrutsche, Kraftwerk, Pretschuhalm, Wasserfall) of approximately $600 \mathrm{~m}$ in total built the base for this study (Figure 1). Furthermore, 350 samples from sections, as well as additional sampling points for regional correlation (K/Pg 2, Sommerauer), of sandstones, siltstones, marls, marly limestones, and shales were taken for sedimentary petrographic and biostratigraphic lab examinations using methods such as thin section analysis (lithology, mineralogy, classification; thin section modal analyses with opaque minerals and various heavy minerals summarized as other grains; at least 300 grains were counted), translucent heavy mineral analysis (section correlation, provenance), calcareous nannoplankton analysis (section correlation, biostratigraphy), and microprobe analysis (heavy mineral geochemistry, provenance).

Biostratigraphy of calcareous nannofossils was performed according to the standard smear slide technique of Bown and Young [44], using standard zonations from Martini [45], Okada and Bukry [46], Aubry and Salem [47], and Agnini et al. [48]. The nannofossil smear slides were studied with a Leica DM 2700P light microscope with $\times 1000$ magnification in bright field (BF), phase contrast (PC), and cross polarized light (XPL).

Of the 70 heavy mineral samples, 48 were prepared using tetrabromethane (TBE), and 22 were separated with a less toxic tungsten-based heavy liquid (LST Fastfloat(c)). Sandstones were dissolved in $40 \%$ acetic acid to loosen the grains, sieved to retain the grain size fraction between 0.4 and $0.063 \mathrm{~mm}$, and separated in separatory funnels with TBE or LST, with a density of $2.95 \mathrm{~g} / \mathrm{cm}^{3}$ (cf. Boenigk [49]). Heavy minerals treated with TBE had to be rinsed with acetone, and samples prepared with LST were rinsed with distilled water. All heavy minerals were embedded in Canada balsam(c) and covered. Identification and counting was performed by using a Nikon Optiphot2-Pol microscope, and at least 300 grains of heavy minerals per sample were counted or, respectively, all grains in samples with fewer than 300 .

A total of 48 thin sections, mostly from sandstones of various grain sizes, were used for petrographic classification. All of these samples were partly stained using Alizarin Red S and potassium ferricyanide to distinguish calcite and dolomite of the cements and carbonate components and to gain qualitative information about their iron contents [50].

Five garnet-rich heavy mineral samples were used for further mineral chemistry examination by an electron microprobe. Garnets of the $0.063-0.4 \mathrm{~mm}$ sieve fraction were embedded in carbon mounts and then polished. Elemental analyses of carbon-coated minerals were conducted with a Cameca SX 100 electron microprobe analyzer (acceleration voltage of $15 \mathrm{kV}$ ) at the Department of Lithospheric Research, University of Vienna.

\section{Results}

\subsection{Biostratigraphy}

Samples from the outcrop sections Wasserfall (WF, 15 samples, thereof 2 barren), Brücke (BR, 6 samples, thereof 1 barren), Hirschrutsche (Hiru, 31 samples, thereof 30 barren), Kraftwerk (KW, 16 samples, thereof 9 barren), Grafenalm (GR, 16 samples, thereof 10 barren), and Gamsforst (GF, 29 samples, thereof 4 barren) were analyzed for nannofossils. In general, nannofossil assemblages were highly diverse and contained poorly to well preserved specimen. Because samples were taken from turbiditic successions, distinguishing autochthonous material from reworked input was a major challenge, especially regarding species with a broad stratigraphical range (e.g., Coccolithus sp., Prinsius sp., Sphenolithus sp., and Toweius sp.).

The samples collected for this work give mainly evidence of the nannofossil zones NP4 to NP11 (Danian-Ypresian) for the studied turbidite-dominated outcrop sections. A more complete range of the Paleocene to the lower Eocene nannofossil standard zones NP1 to NP12 is documented by including previously described sections at Gams: The $\mathrm{K} / \mathrm{Pg}$ boundaries at Knappengraben (KP1) and Gamsbach (KP2) are well defined and have 
already been described in detail [22,29-31,33,35]. At KP1, Zone NP1 [45] is characterized by the occurrence of Markalius inversus and Thoracosphaera (Operculodinella) operculata [22,35]. At KP2, the lowermost Danian is distinguished from the uppermost Maastrichtian intervals by an increased abundance of the calcareous dinoflagellate cyst Operculodinella operculata, followed by an acme of Neobiscutum parvulum [33], both being part of NP1—the Markalius inversus Zone. Zones NP2 to NP4 and NP9 to NP12 are also known from the Gamsbach section, together with the deposits from the Krautgraben and Sommerauer sections, the entire interval from NP1 to NP12 has been verified [22,29], and stratigraphic correlation of the individual logged sections in this study has been specified at high resolution [51].

\subsection{Lithology, Petrology, and Sedimentology}

\subsubsection{Sedimentological Description of Sections}

The examined sections can be described as predominantly consisting of gray sandy and silty graded beds, including fine breccia layers at the base, to silty shales or claystones on top (Figure 3). Grading from coarse base to fine tops is ubiquitous. The shales are mostly dark gray and reach thicknesses of up to several centimeters. Normal grading, lamination, amalgamation of sandy beds, and bioturbation are characteristic for all sections. The thickness of sandstone beds varies strongly from only centimeters to several meters, but in general, sandy beds get thicker at sections dated late Selandian in age or younger.

Sandstone beds show clearly complete and incomplete Bouma sequences, including, from base to top, a graded coarse sandstone interval Ta, often with flute casts at the bases, a horizontally laminated interval $\mathrm{Tb}$, a cross-laminated to convolute bedding interval $\mathrm{Tc}$, and a silty laminated Td interval followed by Te shales and marls [1]. Within thinner beds, Bouma Tbcd intervals are present. Thus, most sections contain sequences of (very) thin- to medium-bedded, fine-grained turbidites. Mass-flow deposits and slump beds are prominent features, the latter more frequent in the stratigraphically lower parts of the succession, within the Nierental Fm. Up to $4 \mathrm{~m}$ thick massive marls, marlstones, and marly limestones intercalated between turbidite beds have gray, light gray, greenish-gray, red, russet, and brownish colors and do not show any visible bedding; sometimes the marls are mottled [22].

The carbonate contents vary strongly throughout the sections (see also [22,34]). In general, the lower (i.e., Selandian) intervals are more carbonatic and well cemented, turning into poorly cemented, carbonate-poor beds in the upper Thanetian. Then the sandy turbidites become rich in carbonate again, with additional marls intercalated between sandstone/siltstone beds. Flute casts indicate a paleotransport direction from SW to NE.

Four stratigraphically distinct facies assemblages are associated with the examined sediments (Figure 2). Facies 1 consists of predominantly gray and red marls/marly limestones, intercalated with thin sandy and silty, carbonate-rich turbidites. Facies 2 is dominated by carbonate-rich turbidite successions and several intercalated gray and red marlstone beds. Facies 3 contains carbonate-poor turbidites, mainly poorly cemented sandy, silty, and muddy turbidite beds. Facies 4 is characterized by gray, reddish, and greenish marl-bearing turbidites. The turbiditic sandstone beds of Facies 4 are thicker and more common than in Facies 1 . Facies 1 is correlated to the Nierental Formation, and the other three facies are part of the Zwieselalm Formation. Slump beds and mass-flow deposits are common, especially in the lower intervals of the Zwieselalm Formation and in the examined Danian segment of the Nierental Formation.

\subsubsection{Thin Section Analysis}

Sandstones are classified as lithic arenites (Figure 4) [52], mainly composed of quartz grains and lithic fragments (e.g., schists, phyllites, limestone, and dolomite) from sedimentary and metamorphic sources (cf. Table 1). The total quartz content ranges between $20.3 \%$ and $45.6 \%$. Minor amounts of feldspar $(2.1-6.3 \%$, thereof $0.0-2.2 \%$ plagioclase and $1.3-4.1 \%$ potassium feldspar), muscovite, chlorite, biotite (total amount of micas $0.3-5.1 \%$ ), hornblende, and iron oxides (e.g., pyrite) are present. Bioclasts are common and vary 
strongly in size. Quartz grains are both monocrystalline (4.3-36.3\%) and polycrystalline $(8.2-23.3 \%)$. The grains are mostly subrounded to angular, and in some cases, rounded or very angular grains appear. The sorting is generally moderate to poor, although some individual thin sections of parts of Bouma intervals are better sorted. The arenites are generally grain-supported, though minor amounts of clayey, silty, and micritic matrix are present $(0.0-4.3 \%)$. The sandstones are bound by cements $(10.5-36.6 \%)$, which primarily consist of calcite (iron-bearing as well as free of iron) and iron-bearing dolomite. Additionally, iron oxide cements co-occurred. Bioclasts (0.0-13.7\%) included complete planktonic and benthic foraminifera (e.g., Discocyclina spp., Globigerina spp.), echinoderms, bryozoans, algae (e.g., corallinaceae), bivalves, gastropods, and brachiopods, as well as fragments thereof. Within single thin sections, layers of accumulated heavy minerals (primarily opaque minerals, some garnets, tourmaline, zircon, and staurolite) were observed. Modal compositions of the lithic arenites are presented as Supplementary Material (Table S1).
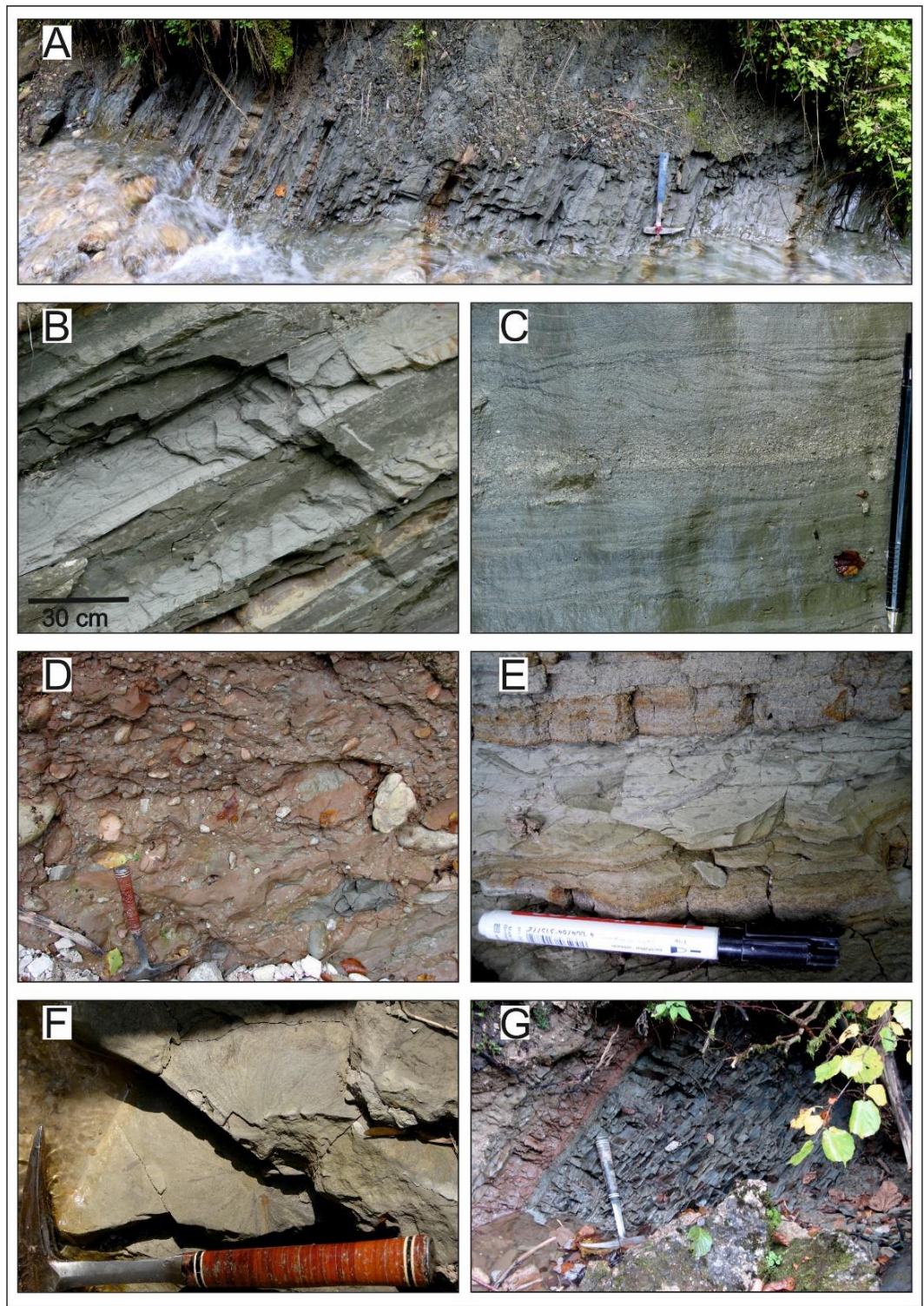

Figure 3. Overview on field sedimentology and sedimentary structures of the Upper Gosau Group of Gams. (A) General outcrop situation, base to top from right to left. (B) Bouma sequences. (C) Turbidite bed with normal grading, lamination, and convolute bedding. (D) Slump bed. (E) Bioturbated marl with medium-grained sandstone bed on top. (F) Zoophycos ichnofossil. (G) Red and gray marls. 


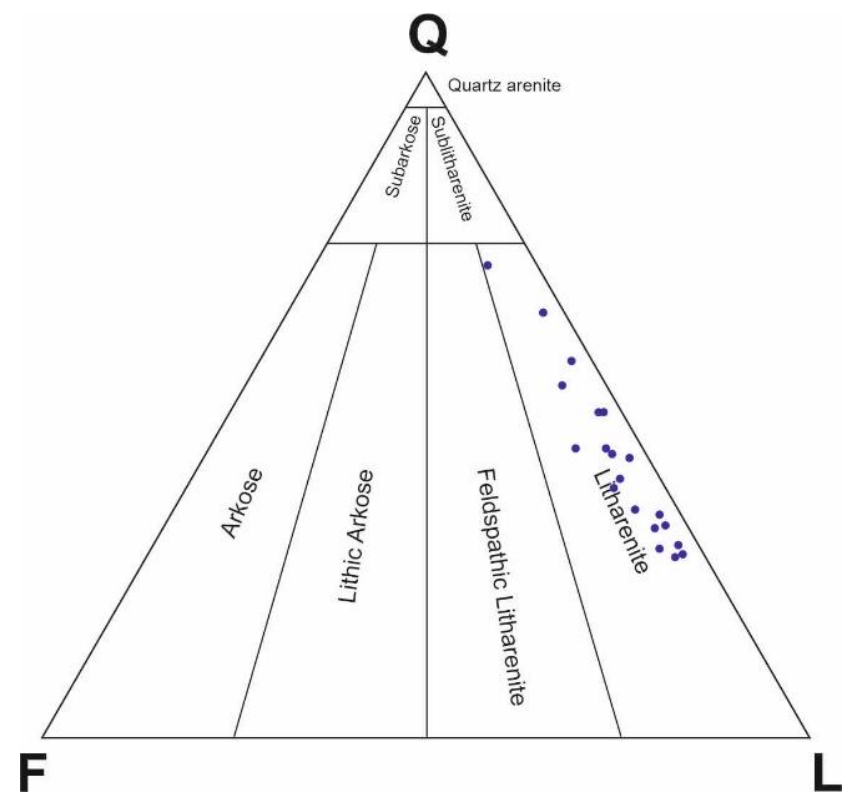

Figure 4. (Q,F,L) sandstone classification diagram [52] of the Paleogene Gams samples.

Table 1. Sandstone grain types and characteristics of turbidite sandstones of the Zwieselalm Formation of Gams and their source and provenance interpretation.

\begin{tabular}{|c|c|c|c|c|}
\hline Sandstone Grain Type & Composition/Texture & Mineralogy & $\begin{array}{c}\text { Heavy } \\
\text { Minerals }\end{array}$ & $\begin{array}{c}\text { Source/Provenance } \\
\text { Interpretation }\end{array}$ \\
\hline Biogenic carbonate & $\begin{array}{l}\text { Planktic and benthic } \\
\text { foraminifera, red } \\
\text { algae, bryozoa, } \\
\text { echinodermata, peloids }\end{array}$ & Calcite & None & $\begin{array}{c}\text { Small syndepositional } \\
\text { biogenic buildups at } \\
\text { southern margin } \\
\text { of NCA }\end{array}$ \\
\hline Carbonatic lithic gains & $\begin{array}{l}\text { Cemented limestone and } \\
\text { dolostone with various } \\
\text { fossils/fossil fragments } \\
\text { and grains }\end{array}$ & Calcite, dolomite & None & $\begin{array}{c}\text { Reworked and } \\
\text { redeposited Triassic, } \\
\text { Jurassic, and Lower } \\
\text { Cretaceous carbonate } \\
\text { formations of the NCA }\end{array}$ \\
\hline $\begin{array}{c}\text { Mixed } \\
\text { carbonate-siliciclastic } \\
\text { lithic grains }\end{array}$ & $\begin{array}{c}\text { Quartz, limestone, } \\
\text { dolostone, biogenic } \\
\text { carbonate fragments } \\
\text { including Upper } \\
\text { Cretaceous foraminifera }\end{array}$ & $\begin{array}{c}\text { Quartz, calcite, } \\
\text { dolomite, low amounts } \\
\text { of feldspar }\end{array}$ & $\mathrm{Cr}, \mathrm{Zr}, \mathrm{Ru}, \mathrm{Tu}, \mathrm{Ap}$ & $\begin{array}{c}\text { Reworked and } \\
\text { redeposited Lower } \\
\text { Gosau Subgroup rocks } \\
\text { of the NCA }\end{array}$ \\
\hline $\begin{array}{l}\text { Silty shale and phyllite } \\
\text { lithic grains }\end{array}$ & $\begin{array}{l}\text { Shaly matrix with } \\
\text { silt-sized grains }\end{array}$ & $\begin{array}{l}\text { Clay minerals and } \\
\text { small-sized mica, } \\
\text { silt-sized quartz, minor } \\
\text { silt-sized feldspar }\end{array}$ & $\begin{array}{l}\text { None or silt-sized } \\
\text { Zr, Ru, Tu, Ap }\end{array}$ & $\begin{array}{l}\text { Anchimetamorphic to } \\
\text { low-grade } \\
\text { metamorphic rock } \\
\text { fragments of GWZ } \\
\text { and UAA }\end{array}$ \\
\hline $\begin{array}{l}\text { Lithic grains } \\
\text { including quartzite, } \\
\text { mica-quartz-schists, } \\
\text { mica schists }\end{array}$ & $\begin{array}{l}\text { Recrystallized texture } \\
\text { of quartz }\end{array}$ & $\begin{array}{l}\text { Quartz, mica, } \\
\text { minor feldspar, }\end{array}$ & $\begin{array}{c}\text { Gr (almandine), St, } \\
\text { Ep, Tu, Zr }\end{array}$ & $\begin{array}{l}\text { Low-grade to } \\
\text { medium-grade } \\
\text { quartz-rich } \\
\text { metamorphic rock } \\
\text { fragments of UAA }\end{array}$ \\
\hline $\begin{array}{l}\text { Platy lithic quarzite to } \\
\text { gneiss grains }\end{array}$ & $\begin{array}{l}\text { Strongly recrystallized } \\
\text { texture of quartz }\end{array}$ & Quartz, mica, feldspar & $\begin{array}{l}\text { Gr (almandine- } \\
\text { pyrope), St, } \\
\text { Ky, Ti }\end{array}$ & $\begin{array}{l}\text { Higher-grade } \\
\text { metamorphic rock } \\
\text { units from UAA }\end{array}$ \\
\hline
\end{tabular}

$\mathrm{Ap}=$ apatite, $\mathrm{Cr}=$ chromite, $\mathrm{Ep}=$ epidote, $\mathrm{Gr}=$ garnet, $\mathrm{Ky}=$ kyanite, $\mathrm{Ru}=$ rutile, $\mathrm{St}=$ staurolithe, $\mathrm{Ti}=$ titanite, $\mathrm{Tu}=$ tourmaline, $\mathrm{Zr}$ = zircon, Northern Calcareous Alps (NCA), Greywacke Zone (GWZ), Upper Austroalpine basement units (UAA). 


\subsubsection{Heavy Mineral Analysis}

The heavy mineral assemblages of Gams from the uppermost Nierental Formation and the Zwieselalm Formation are quite uniform and homogenous, with only minor variations. The predominance of garnet is an obvious feature of heavy mineral assemblages of the Paleogene Gosau Group of Gams (Figure A1). The amount of garnet ranged between $33 \%$ and $66.5 \%$, with a mean $49.5 \pm 8.2 \%$ standard deviation. Most garnets are colorless, but some bigger grains are pale pink. Concerning the stable minerals zircon, tourmaline, and rutile (ZTR group), tourmaline is the most frequent mineral (19.1 $\pm 5.4 \%)$, followed by rutile/brookite/anatas $(5.6 \pm 2.2 \%)$. Minor amounts of other heavy minerals, such as apatite, kyanite (disthene), epidote/zoisite, different amphiboles, including hornblende and glaucophane, and chloritoid are identified. Chromite, which is abundant in the Lower Gosau Subgroup heavy mineral spectra, is missing in most of the samples. Only sections of the early to the middle Paleocene age comprise minimum amounts of chromite (e.g., samples WF-25, WF-28, BR I-05).

\section{Discussion}

Based on sedimentology, section correlations, paleocurrent data, sediment petrography, and garnet mineral chemistry, the sedimentary environment and the provenance of the Paleogene Upper Gosau Group of Gams can be evaluated. A deep-water environment of at least several hundreds of meters was already suggested for the Paleogene Gams Basin based on foraminiferal assemblages, including high numbers of planktonic and deep-water agglutinated foraminifera $[19,22]$. A mainly southern provenance for the clastic material of this part of the basin fill could be interpreted and is in accordance with former interpretations of the Upper Gosau Subgroup in other Gosau basins (e.g., [22,29,31,33,34,53]).

\subsection{Classification of Sandy Turbidites of the Paleogene Upper Gosau Group of Gams}

Based on field data, sedimentological structures, and grain size, most beds are to be characterized as classic turbidites and can be described using the Bouma sequence or at least parts of the Bouma sequence [1]. Complete intervals Ta to Te are scarce, but Tbcd intervals are often visible. The transition from $\mathrm{Td}$ to $\mathrm{Te}$ is difficult to recognize in the outcrops, as respectable beds of pure mud are often missing, possibly as an effect of erosion, originating from an overlying turbiditic bed. Breccia layers at the base of turbidites are interpreted as channel or chute fills. Referring to Walker [6,54], the sedimentary successions can be classified as "classic" or "classical turbidites". The deposits from the Upper Gosau Group of Gams show specific features of this classification, such as erosional casts at the base, internal sedimentary structures such as graded bedding and lamination, and an alternation of sand and shale [6].

Comparing the Paleocene-Eocene sediments of Gams with the classification described by Pickering et al. [11], the succession is categorized as "Facies Class C: sand-mud couplets and muddy sands", which equals the classical turbidites of Walker [6]. Specifying the classification in greater detail, the Gams turbidites belong to "Facies Group C2: organized sand-mud couplets" [11]. Based on field data, sandy/silty turbidite beds were classified into thickness categories on a logarithmic scale. Beds of 11-100 mm prevail, while beds of 101-1000 mm are slightly more frequent than beds of 1-10 $\mathrm{mm}$ [51]. Sandy turbidites of more than $1001 \mathrm{~mm}$ are quite rare (only seven of the examined beds). According to the facies classification by Pickering et al. [11], turbidites $<10 \mathrm{~cm}$ are classified as Facies C2.3; thus sandy deposits of the Gams Basin were predominantly sedimented by dilute currents and/or were occasionally the result of turbidity currents of intermediate character (Facies $\mathrm{C} 2.2,10-30 \mathrm{~cm}$ ). The data, including intervals of thin- to medium-bedded, fine-grained turbidites in all sections, individual beds that pinch out, and the absence of thicker key beds, which could be traced across the basin for correlation, also indicate that the Gams turbidite system and the amount of sediment supply were rather small, compared with the unconfined, voluminous fan complexes fed by large (recent) rivers such as the Mississippi, Amazon, or Indus system. 


\subsection{Provenance of the Paleogene Upper Gosau Group of Gams}

The variability in detrital chromite and garnet provides probably the best evidence on provenance and the depositional history of Gosau basins during the Cretaceous and Paleogene $[23,53,55]$. A shift from chromite-rich spectra to garnet-rich assemblages happened mostly during the Campanian, reflecting a change in the source of the delivered material from (ultra)mafic to metamorphic compositions [56].

A chronological classification of the Danian, Selandian, Thanetian, and Ypresian heavy mineral samples of Gams shows that the assemblages do not break down into different groups; therefore, no changes in composition or sources are indicated during the Paleogene. All of the Paleogene turbidites of the uppermost Nierental Fm and the Zwieselalm Fm comprise similar and homogenous heavy mineral assemblages, dominated by stable minerals (ZTR) and minerals from metamorphic sources (garnet, staurolite, lesser amounts of epidote group minerals, and amphiboles).

The enrichment in (ultra)stable minerals points to moderate reworking of the delivered material, deposited mainly as sandy turbidites [57,58]. An input of chromite, which is known from many Gosau successions in different Upper Cretaceous Gosau basins, derived from ophiolitic sources [53,55,59], is not present at all within the Paleocene-Eocene part of the Gosau Group of Gams. Scattered chromite grains found in some samples are reworked from the chrome spinel-rich Lower Gosau Subgroup. The characteristic increase of staurolite in Paleocene assemblages of the Gams Basin [56], but also in other Gosau basins [53], can be confirmed. Blue sodic amphiboles (glaucophane-riebeckite series) were rare $(<1 \%)$, but continuously encountered in the samples; these are known as high-pressure, low-temperature metamorphic index minerals. The smaller number of kyanite grains suggests a provenance including higher-pressure metamorphic facies [60].

By taking a closer look at provenance indexes based on heavy mineral assemblages, it is possible to infer the metamorphic facies of the main sediment sources $[58,61,62]$. Classifications by Garzanti et al. [61], based on ZTR, garnet, amphiboles, staurolite, and other heavy minerals, indicate the dominance of an upper greenschist to lower amphibolite facies source of the investigated Paleocene to Eocene sediments [51]. The appearance of kyanite together with the lack of sillimanite supports this assumption.

Thin-section petrography suggests a mixed siliciclastic-carbonate provenance. The investigated turbiditic sandstones, mostly rich in carbonate, contained a great diversity of lithic fragments and quartz. Lithic fragments (on average 39\%, up to 53\%) included larger amounts of low- to medium-grade metamorphic lithoclasts, such as (mica-rich) schists, phyllites, polycrystalline quartz, and other material of metamorphic provenances, partly showing strong alterations. However, also carbonate lithic grains of limestones and dolomites are encountered.

The lithic arenites from the Paleocene Gosau Group show a peculiar composition for sandy turbidites, due to the source area, the metamorphic basement units of the Austroalpine, and the extended reworking processes at the southern margin of the NCA and across the shelf of the Austroalpine microplate. Similar to heavy mineral assemblages, the frequently found phyllite and schist fragments indicate that they were part of a greenschist to amphibolite metamorphic facies, commonly known from the Austroalpine units in the Eastern Alps [63]. The abundance in polycrystalline quartz, together with the high amount of rock fragments within individual polycrystalline quartz lithoclasts, emphasizes a low-grade metamorphic provenance [64].

On the other hand, a broad variety of bioclasts and calcareous lithic fragments are found. The latter are interpreted as reworked material of the Lower Gosau Subgroup and older NCA units, as well as recycled sediments of the Upper Gosau Subgroup. The occurrence of a variety of shallow-marine bioclasts, such as foraminifera and corallinacea, including blocks of Paleogene limestones also shows the influence of a contemporaneous active carbonate shelf, assumed to be situated in the south of the NCA, at the shallowmarine segment of the slope $[23,55]$. Most likely, sandy material of the Upper Gosau Group was also reworked by mass flows, which is backed up by reworked Paleogene nannofossils 
as well. Subrounded to angular grains point to minor reworking and sediment transport over a shorter distance. Based on heavy mineral assemblages, thin section analysis, and paleotransport directions, a steady source delivering detritus from metamorphic host rocks south of the Gams depocenter during Paleocene to Eocene is evident. Thus, the NCA and metamorphic units of the Upper Austroalpine were most probably the provenance for the Paleogene sedimentary deposits of the Upper Gosau Group of Gams (Figure 5).

\section{PALEOCENE}

$\mathbf{N}$

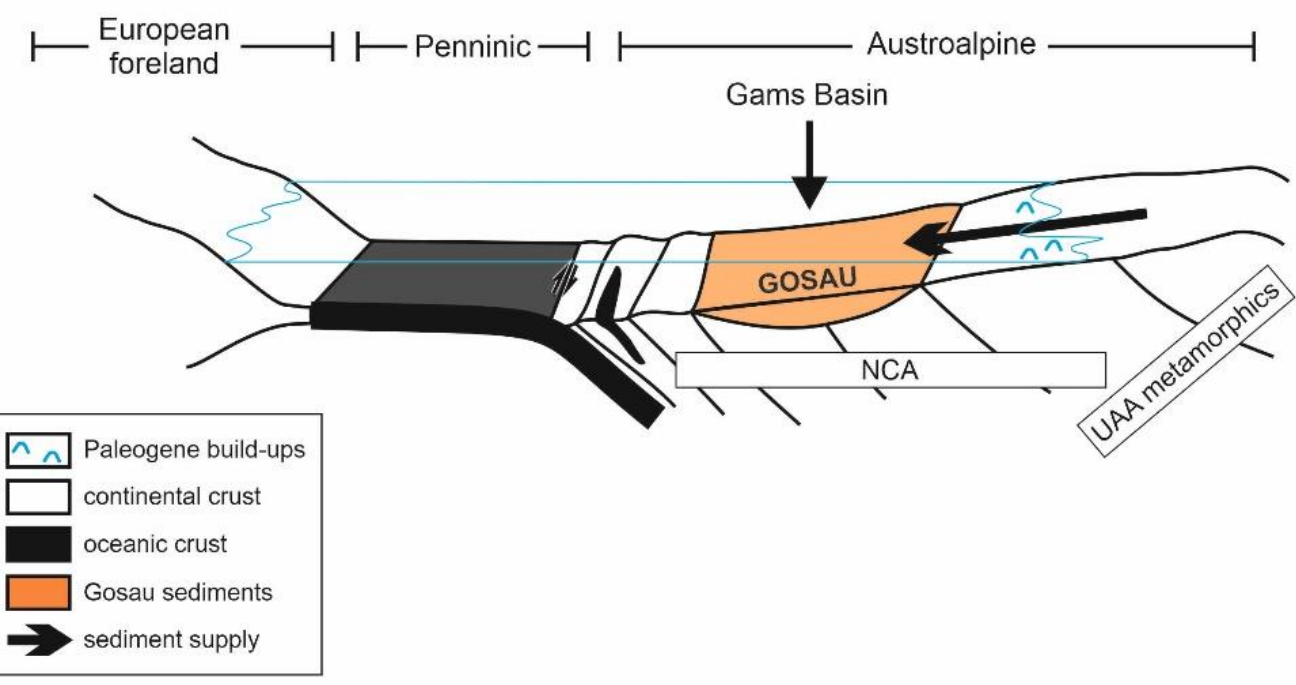

Figure 5. Paleogeographic model of the European/Helvetic and Austroalpine/Adriatic microplate, including the depocenter of the Upper Gosau Group of Gams (NCA), not to scale. Modified from [53].

In general, the exhumation of rising Austroalpine metamorphic basement complexes, south of the NCA, generated the primary source for the Paleogene Gosau deposit siliciclastics [19]. The Upper Austroalpine unit (UAA) represents a complex nappe stack affected by eoalpine overprint, which is subdivided into several basement complexes: The Silvretta-Seckau nappe system overprinted by subgreenschist to amphibolite facies conditions during the eoalpine event is overlain by the Paleozoic Greywacke Zone and the NCA Juvavic/Tirolic/Bajuvaric nappes (with the Gosau Group on top), consisting of nonmetamorphosed to greenschist facies sequences $[65,66]$. Another Austroalpine element is the Koralpe-Wölz nappe system, interpreted as an eoalpine metamorphic extrusion wedge, consisting of basement nappes with older HT/LP (up to eclogite conditions, Permian-Triassic) and younger LT/HP (eoalpine) overprint. Today, this extrusion wedge is positioned below the Ötztal-Bundschuh nappe system with the Drauzug-Gurktal nappe system on top (unmetamorphosed to greenschist facies sequences) with diagenetic to amphibolite facies with eoalpine overprint for the latter two $[63,65,66]$.

During the Cretaceous eoalpine orogenic event, the Koralpe-Wölz wedge exhumed high-pressure rocks (up to eclogite facies conditions) between the lower plate (SilvrettaSeckau nappe system) and the upper plate (Ötztal-Bundschuh and Drauzug-Gurktal nappe systems), which formed during the subduction of parts of the Meliata Ocean/Neotethys suture $[65,67,68]$ (Figure 6). Prior to maximum burial and exhumation of the Upper Austroalpine basement units in the Turonian (ca. 94-90 Ma), parts of the Paleozoic and Mesozoic (NCA) cover units, representing deposits of the shelf, originally facing towards the Neotethys (Meliata Ocean), were detached and stacked upon one another in a transpressional top-NW setting from the earliest Cretaceous (Valanginian) onwards. These nappes, forming the NCA, were only non- to weakly metamorphosed and mirror the beginning 
of the eoalpine orogeny $[63,66]$. Gosau Group sediments represent syn- and postorogenic detritus of this eoalpine orogeny [55], marking a distinct separator between the eoalpine (Cretaceous) and the mesoalpine (Paleogene) orogenic events [65].

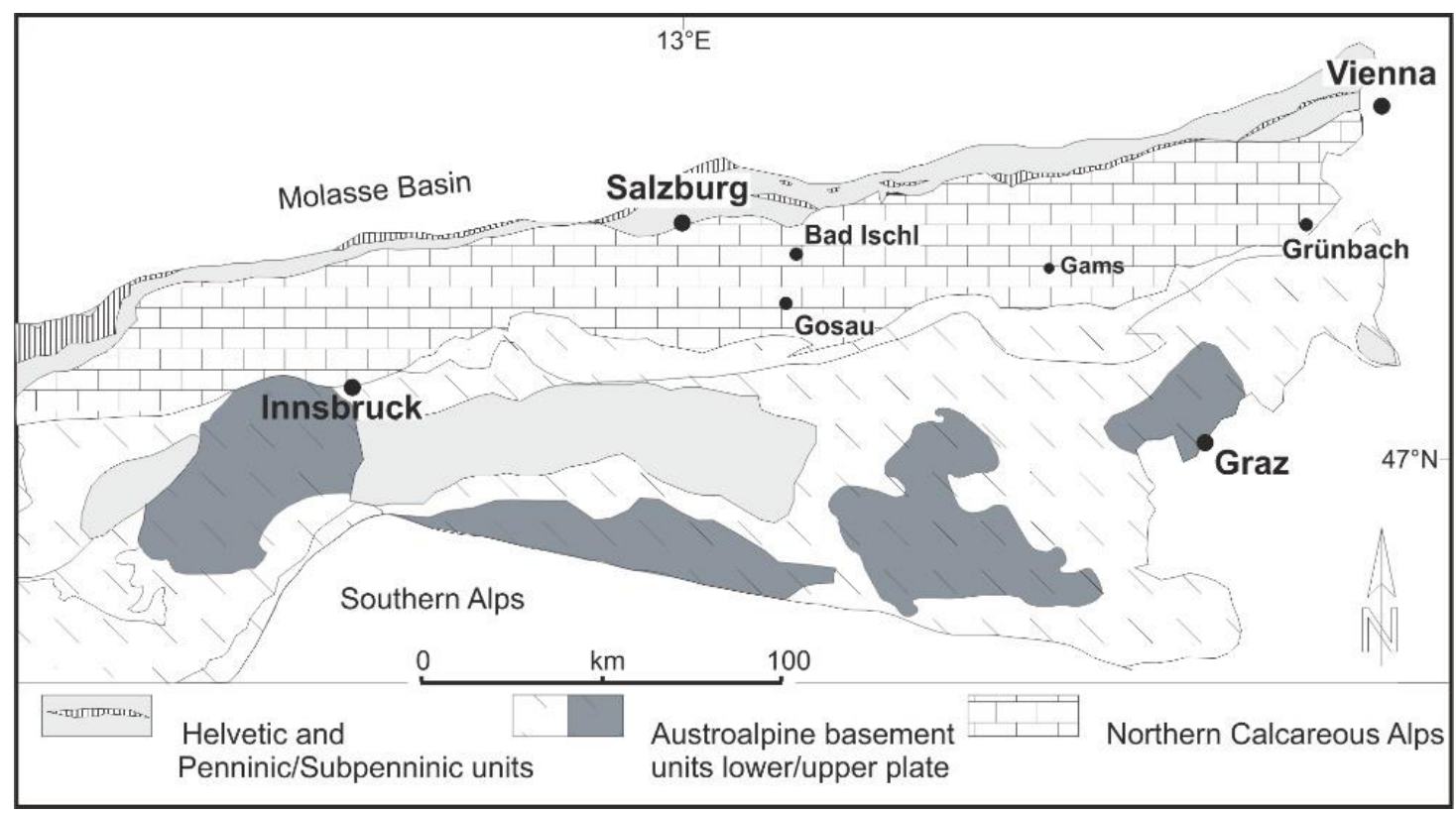

Figure 6. Geological sketch of Austria, including Austroalpine basement units subdivided into lower (Silvretta-Seckau nappe system, Koralpe-Wölz nappe system) and upper plate (Ötztal-Bundschuh and Drauzug-Gurktal nappe system) and the NCA with selected Gosau localities mentioned in the text.

The chemical compositions of the examined garnets (Table S2) and the mineral composition of heavy mineral assemblages of the Paleogene sediments of Gams show strong similarities to garnets occurring in Austroalpine crystalline units, such as the Wölz, Rappold, Sau-Koralpe, and Gleinalpe complexes [69]. These almandine-rich garnets [69] are derived from low- to medium-grade metamorphic (metapelitic) sources. The lack of garnet, rich in pyrope and grossular, characteristic of higher metamorphic units, indicates that those units of the southern Neotethys suture were already eroded during the Paleogene, a development also known from other Gosau basins (cf. $[23,53,66])$. Blue sodic amphiboles (glaucophane-riebeckite mineral series) found in heavy mineral assemblages are signs of high-P metamorphic conditions. However, their rare occurrence, together with very rare kyanites, suggests recycling of those single grains, from Lower Gosau Subgroup rocks, where such heavy minerals are reported [70] similar to the scarce reworked chrome spinel grains in the assemblages of Danian samples from Gams.

\subsection{A Model for the Slope Depositional System of the Gams Gosau Group}

A comparison of the depositional system of the Upper Gosau Subgroup of Gams with traditional submarine fan models of turbidite/deep-water deposition (e.g., $[2,3,5,10,14]$ ) is complicated due to the model premise of an unconfined, often large turbidite complex, which developed on the slope and expanded further at the toe of slope. Moreover, the Gams slope basin provided a fairly small depositional area and accommodation space on the incipient Alpine orogenic wedge, and the pervasive tectonic deformation of the NCA destroyed and obscured important features of the formerly confined source-to-sink system.

\subsubsection{Depositional Model}

Regarding the type of slope and the position of the Late Cretaceous-early Paleogene Gams Basin on the slope, an out-of-grade depositional system at a bathyal depth of approximately $2000 \mathrm{~m}$ is most likely, as also proposed for the basin of the Gosau-Group type 
area [71]. Paleobathymetric reconstructions based on foraminiferal assemblages support a lower bathyal to upper abyssal environment $[19,22]$.

The facies of the Upper Gosau Group of Gams shows characteristics of ponded-basin accommodation space (i.e., accommodation within three-dimensionally closed/confined topographic lows (e.g., synclines)) [16]. A graded slope can be ruled out, which would be characterized by unconfined deposition at the toe of slope and at the basin floor, with gravity flows bypassing the upper/middle parts of the slope, generating laterally continuous sandy submarine fans or aprons [16]. Deposition in this ponded accommodation space within intraslope basins is mainly controlled by "fill-and-spill" processes $[16,39,72]$. No healed slope and slope accommodation space below grade $[16,72]$ is evidenced because successions of large wedge-shaped slope deposits, slope aprons, and thick capping shale beds do not exist at Gams. Furthermore, the sand-to-mud ratios are high in almost all sections at Gams. A deposition within an incised submarine valley accommodation space [16] is equally unlikely since the size of submarine valleys is typically larger and deposits in canyons are characterized by large (highly) sinuous channel complexes, which were not detected at Gams.

Paleoflow directions of the Upper Gosau Subgroup of Gams are quite uniform, indicating a submarine fan system with a single feeder (Figure 7). However, the existence of more than one fan or a minor shift or switch of the feeder channel cannot be excluded due to restricted stratal record and strong tectonism during and after deposition.

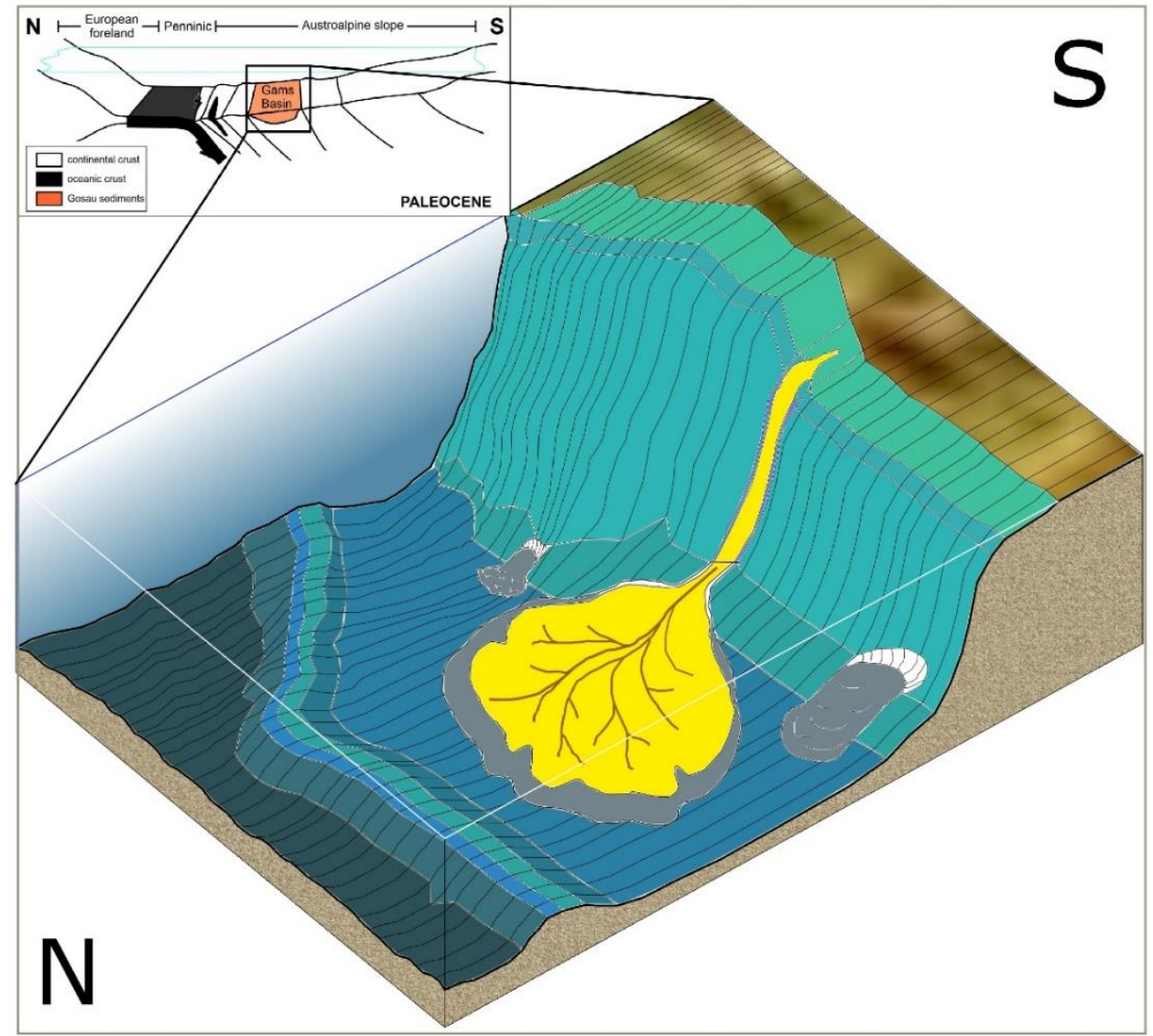

Figure 7. Sketch of the sandy depositional system model of the small and confined Gams slope basin (not to scale).

With regard to the paleogeographic and paleotectonic position of the depositional system of Gams, similarities to, for example, the Swiss Taveyannaz sandstones are given: This turbiditic succession was deposited in two sub-basins at the frontal margin of the submarine Alpine thrust wedge, filled up by "fill-and-spill" processes [39]. A highly active tectonic setting is also assumed for the sedimentary succession of Gams due to the presence 
of slumps and olistostromes, giving evidence for ongoing eoalpine orogeny [21,23]. The most obvious difference from models dealing with confined turbidite basins, such as the Taveyannaz sandstones (e.g., $[39,73]$ ), is the absence of a second basin. Whether a second adjacent "sister" basin (or a cascade of basins) never existed or was later on masked by tectonic deformation and/or erosional processes is not known so far. Stratigraphic correlations to other (Upper) Gosau Group sediments close to the Gams area as possible depocenters, formerly linked to the Gams Basin, are interfered by the nature of fill-and-spill processes, mismatches in biostratigraphic dating, and again erosion and tectonism. Some of the nearby Gosau Group successions contain only sediments up to the Maastrichtian or the early Paleocene, and other close-by areas show only hemipelagic deposits; thus rapid facies changes and changing bathymetric conditions are common $[19,74,75]$.

Concerning considerations of the size of the receiving basin versus the size of incoming turbidity flows, the Gams Basin was most probably small (today's dimension of $12 \mathrm{~km} \times 5 \mathrm{~km}$ ), but also the turbidity currents entering it seem to have been small scale. The paleoflow directions are uniform, though strong ponded flows should show different directions due to the reflection and deflection of the confined turbidity current $[39,73]$. Thus, the turbidite system was rather uninfluenced by confining barriers. On the other hand, the deposition of grain sizes from sand to silt/mud within a turbidite bed is a common feature in sections of the Gams area. Therefore, turbidity currents were completely trapped and ponded (cf. [39]). Some sections (e.g., Brücke) show characteristics of flow stripping, as their turbidite beds contain (graded) sandstones only. These sand-prone packages represent potential channel-fill facies of distributary channels of the deep-sea fan.

\subsubsection{Comparison with a Recent Analogue}

The well-studied, small, partly confined slope basins of the California Continental Borderland serve as an appropriate Quaternary to a recent equivalent of the Late CretaceousPaleogene turbiditic slope basin deposits of the Gams area (Table 2). Especially the Santa Monica Basin [40-42,76] provides a practical analogue for the Paleogene Gams Basin and its turbidite depositional systems. Both basins are or were positioned along an active continental margin, respectively, bound and influenced by (strike-slip) faults related to crustal shortening. The depocenter of the Paleogene sedimentary succession at Gams is situated at the NCA slope in frontal parts of the Austroalpine (Adriatic microplate) to the south, facing the subducting Penninic Ocean/Alpine Tethys/European plate to the north. Subcrustal tectonic erosion of the accretionary wedge during the closure of the Penninic Ocean/Alpine Tethys took place approximately at the same time as the deposition of the Upper Gosau Subgroup [20]. Rapid subsidence and northward (i.e., trenchward) tilting of the NCA, due to subduction tectonic erosion during the Santonian to the Campanian, led to sedimentation of the Nierental Formation and the Zwieselalm Formation in bathyal to abyssal depths $[21,55]$. The confined Gams and the Santa Monica slope basins are/were located at similar depositional depths, although the Gams area most likely reached greater depths during prolonged subsidence [21,22], and both basins comprise coarse-grained turbidite systems. Within the Santa Monica Basin, four turbidite fans are distinguishable, three of which simultaneously received sediments during the Holocene, even though the sedimentation rates and the distribution shifted, depending on the sea level and thus the connection of the feeder canyon to either rivers or littoral cells [41]. At the Gams area, the number of turbidite fans is masked by syn- and postdepositional tectonics and erosion.

The Gams slope basin comprised one or several small potentially interfingering submarine turbidite fans, but a distinction between different fans based on the clastic material and heavy minerals was not possible. Paleoflow directions indicate that all turbidity currents came from south and southwestern to north and northeastern directions. The volumes of incoming turbidity flows were small in comparison with the available space, since strong ponding of flows would have caused variable paleoflow directions. In addition, most sections throughout the Gams area show parts of thin-bedded turbidites, which points to insufficient volumes of sediment compared with the receiving basin margins [43]. 
Table 2. Comparison of the Paleogene Gams Basin with the Quaternary to the recent Santa Monica Basin [40-42,76] in the California Continental Borderland.

\begin{tabular}{|c|c|}
\hline Santa Monica Basin & Gams Basin \\
\hline Terrigenous sediments & Terrigenous sediments plus biogenic carbonate material (NCA) \\
\hline Small sandy turbidite system & Small sandy turbidite system \\
\hline Mass movement deposits and slope failures common & Mass movement deposits (slumps, olistostromes) common \\
\hline Supply via canyons and slope gullies & Supply via canyons and slope gullies (not preserved) \\
\hline Depth about $1000 \mathrm{~m}$ & Deeper bathyal, approximately $2000 \mathrm{~m}$ \\
\hline Canyon-fan system connected to rivers and littoral cell & Canyon and river system unknown (not preserved) \\
\hline Sandy channel/muddy levee facies & Sandy channel/muddy levee facies \\
\hline Primarily ag & Progradation to aggradation \\
\hline Insufficient volumes of sediment compared with available space & Insufficient volumes of sediment compared with available space \\
\hline Deposition at all sea-level stages & Highstand/sustained system \\
\hline Still active & Abandoned \\
\hline Closed basin, bound and influenced by faults & Closed basin, bound and influenced by faults \\
\hline Active continental margin & Active continental margin (Austroalpine microplate) \\
\hline Strike-slip/transpressional regime & Strike-slip/transpressional regime \\
\hline Narrow shelf & Narrow shelf \\
\hline
\end{tabular}

A similar depositional pattern is known from the Santa Monica Basin, for which there were no signs of strong ponding reported [40,42]. In contrast to the Holocene Santa Monica Basin, a clear identification of the main feeder channel of the Gams system is missing, and due to biostratigraphic gaps, a differentiation into individual lobes was not possible. However, based on field data, segments of the channeled facies and thin-bedded levee facies are interpreted as distributary channels across the fan with levees in between. The supply of siliciclastics by several smaller rivers and/or maybe a minor delta and/or littoral cell(s) across the narrow shelf is most likely.

Considering the general configuration of the composite section from the Danian to the Ypresian, the turbidite complex of the confined Gams slope basin is interpreted as an aggrading or prograding submarine fan, although more 3D data would be needed. The increasing ratios of marlstones, the decreasing bed thickness and input of sandy turbidites, and the fining- and thinning-upward cycles in the Ypresian sections indicate a filling of the channels and the separation of the Gams turbiditic fan(s) from its main source during the Eocene, which is very likely due to ongoing tectonics. Since the thick (hemipelagic) mud caps on top of the turbiditic deposits or backfilling of canyons and channels with fine-grained sediments are unaccounted for (cf. also [22,23,27]), the Gams slope basin was probably never completely filled and cut off in the early Eocene before it reached its spill point.

\subsubsection{Controlling Factors of Deposition in the Gams Basin}

Taking the controlling factors for the depositional development of the Gams slope basin into account (eustatic) sea-level fluctuations, climate, sediment supply, and tectonic influences have to be considered. For the Tethyan realm, warm, largely ice-free greenhouse climate conditions prevailed, with a general warming trend from the $\mathrm{K} / \mathrm{Pg}$ to the early Paleogene, intermitted by short-time low-amplitude cooling during the Selandian [77]. Considering the entire Gosau Group of Gams, from the Upper Cretaceous to the Eocene, the deposits were all sedimented during general greenhouse conditions. A subtropical climate, with enhanced chemical weathering under seasonal conditions, is assumed, which enhanced the erosion and facilitated a greater terrestrial sediment supply into the ocean and the slope basin. Particularly an increased input of siliciclastics around the PETM (Paleocene-Eocene Thermal Maximum) is noticeable, including significant numbers of sandy turbidites (cf. also [22,34]).

The prominent transition of the marl-dominated Nierental Formation during the Selandian to the Zwieselalm Formation, rich in sandy and silty turbidites, represents an essential facies change. Thus, several factors supporting an increased sediment supply 
have to be considered: active wedge tectonism with ongoing strike-slip movements; the previous subsidence history of the Gams slope basin, with strong subsidence across the Santonian-Campanian boundary without any signs of uplift during the late Paleocene and Eocene [21,23]; the greenhouse conditions [22]; and the rising metamorphic Austroalpine crystalline basement units and their adjacent contemporaneous carbonate shelf zones of the NCA as a source area.

Although sandy turbidites are less common and less thick around the PETM, they are, nevertheless, characteristic for this interval at Gams. They represent a high siliciclastic input, regardless of the sea level, and were most probably controlled by the general greenhouse climate with strong seasonal precipitation and runoff. The persisting deposition into the Gams slope basin shows that the feeder channel was capable of keeping a connection to the subaerial source area. The setting at the active margin of the Austroalpine microplate, together with a continuous sediment supply despite a sea-level rise, point toward a rather narrow shelf. In addition, the steady entry of sandy turbidites helped to maintain the feeding channels as well [76] and facilitated the filling of the basin.

Compared with the turbidite depositional models of Covault and Graham [78], the Gams system is an example of a highstand/sustained system, more dependent on climate and tectonic influences than on eustatic sea-level fluctuations. Analogous to the California Continental Borderland [79], the development of the Gams slope basin and its infilling sequences was mostly dominated by regional tectonics and sediment supply, rather than by eustasy.

\section{Conclusions}

Based on field sedimentology, petrology, and mineral chemistry data, a model for the slope basin depositional system of the Paleogene Gams Basin is developed. The results point towards a steady metamorphic and sedimentary source area during the Paleocene and early Eocene (NP1-NP12). The provenance of the Upper Gosau Group of Gams is interpreted as Upper Austroalpine units in the south, originating from the lower- to medium-grade metamorphic Austroalpine crystalline units, such as the Wölz, Rappold, Sau-Koralpe, and Gleinalpe complexes. In addition, carbonate supply was delivered by directly adjacent contemporaneous shelf zones. The depocenter for the Paleogene sedimentary succession of Gams is situated at the NCA slope, in front of the Austroalpine/Adriatic microplate to the south, facing the subducting Penninic Ocean/Alpine Tethys/European plate. Therefore, the evolution of the Gams Basin is strongly connected to the eoalpine (Early Cretaceous) and the mesoalpine (Eocene-Oligocene) orogeny and the adjunctive transpressional setting. At the Gams area, the specific depositional development is obscured by syndepositional and postdepositional tectonics and erosion.

The Gams deep-water depositional system is interpreted as an aggrading or prograding submarine fan, deposited into a small confined slope basin, positioned along an active continental margin, bound and influenced by (strike-slip) faults related to crustal shortening. The slope basin comprised one or multiple small (potentially interfingering) submarine turbidite fan(s). The volumes of incoming, often ponded, turbidity flows were small in comparison with the available space. Based on field data, the segments of channeled facies and thin-bedded levee facies are interpreted as distributary channels across the fan with levees in between. Supply of siliciclastics by smaller rivers across a narrow shelf and littoral cell(s) is most likely and fits the general paleoenvironmental models proposed for the area.

A Quaternary to a recent analogue provides the Santa Monica Basin in the California Continental Borderland. The Santa Monica and Gams Basin are/were both rather small slope basins of comparable depths, although the Gams area most likely reached greater depths during ongoing subsidence. Based on foraminiferal assemblages, middle to lower bathyal depths are supposed for the Maastrichtian-Eocene Gams slope basin.

The development of the Gams slope basin and its infilling sequences was mainly dominated by tectonic influences and sediment supply, most likely controlled by prevailing greenhouse climate, rather than eustatic sea-level fluctuations. Relative sea-level changes 
may have led to more local variations in the sediment distribution across the deep-sea fan(s). The Gams slope basin was probably never completely filled and cut off before it reached its spill point. The increasing ratios of marlstones, the decreasing bed thicknesses and input of sandy turbidites, and fining- and thinning-upward sequences in the Ypresian indicate the filling of channels and the abandonment of the turbiditic fan(s) from the source during the Eocene.

Supplementary Materials: The following are available online at https: / www.mdpi.com/article / 10.3390/min12020178/s1, Table S1: Mineral abundances [\%] of the Gams sandstones; Table S2: Endmember garnets Paleogene sediments of the Zwieselalm Formation (Gosau Group, NCA).

Author Contributions: Conceptualization, methodology, formal analysis, data curation, visualization, and project administration, M.W. and V.K.; validation and investigation, V.K., M.W., M.-E.K. and W.K.; resources, supervision, and funding acquisition, M.W.; writing-original draft preparation, V.K. and M.W.; writing - review and editing, V.K., M.W., M.-E.K. and W.K. All authors have read and agreed to the published version of the manuscript.

Funding: This research was funded by UNESCO IGCP 609 and the Austrian Academy of Sciences, International Programs, IGCP661 and IGCP710. Open Access Funding by the University of Vienna.

Data Availability Statement: The data presented in this study are available in the article and the supplementary material.

Acknowledgments: We thank two anonymous reviewers for their constructive reviews, which considerably helped to focus the paper.

Conflicts of Interest: The authors declare no conflict of interest.

\section{Appendix A}

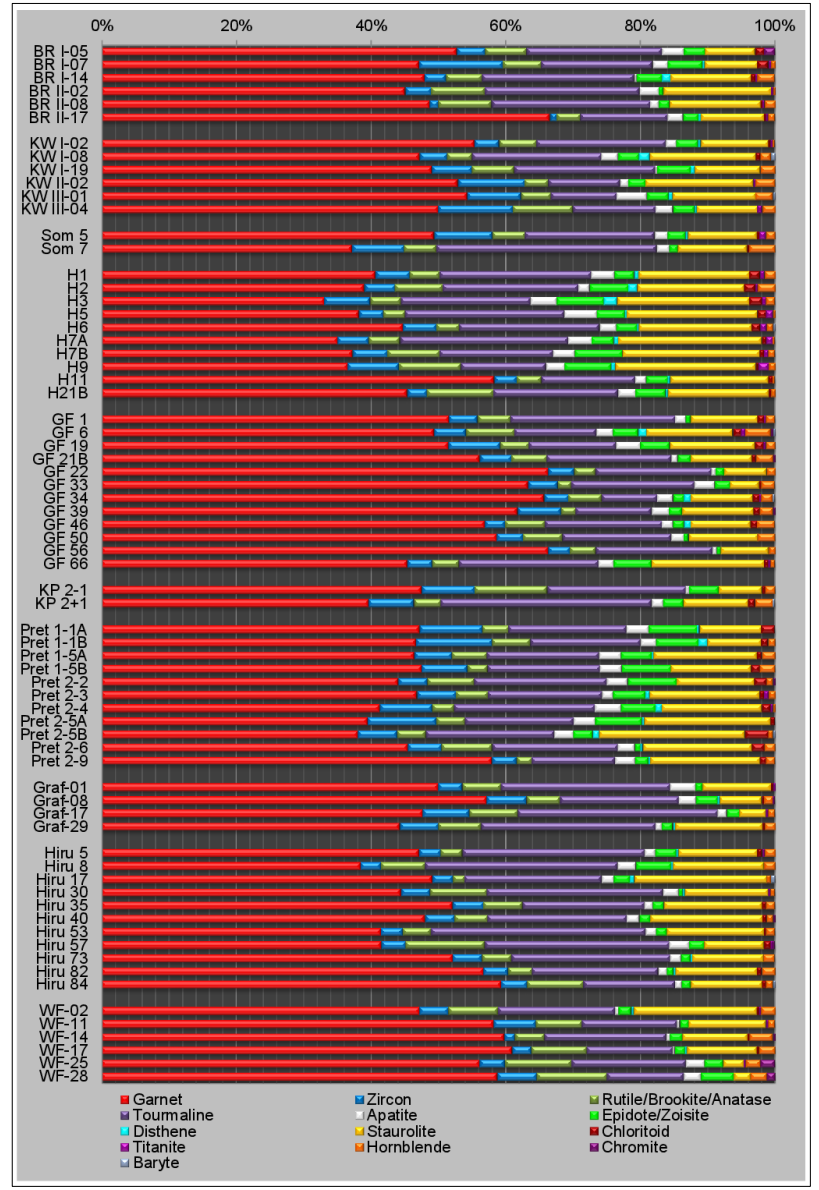

Figure A1. Heavy mineral assemblages of analyzed samples from the Upper Gosau Group of Gams. 


\section{References}

1. Bouma, A.H. Sedimentology of Some Flysch Deposits: A Graphic Approach to Facies Interpretation, 1st ed.; Elsevier: Amsterdam, The Netherlands, 1962; 168p. [CrossRef]

2. Walker, R.G. Turbidite sedimentary structures and their relationship to proximal and distal depositional environments. J. Sediment. Petrol. 1967, 37, 25-43. [CrossRef]

3. Normark, W.R. Growth patterns of deep sea fans. Am. Assoc. Pet. Geol. Bull. 1970, 54, 2170-2195. [CrossRef]

4. Haner, B.E. Morphology and sediments of Redondo Submarine Fan, southern California. Bull. Geol. Soc. Am. 1971, 82, $2413-2432$. [CrossRef]

5. Mutti, E.; Ricci Lucchi, F. Le torbiditi dell'Appennino settentrionale: Introduzione all'analisi de facies. Mem. Soc. Geol. Ital. 1972, 11,161-199.

6. Walker, R.G. Deep-Water Sandstone Facies and Ancient Submarine Fans: Models for Exploration for Stratigraphic Traps. Am. Assoc. Pet. Geol. Bull. 1978, 62, 239-263. [CrossRef]

7. Normark, W.R.; Piper, D.J.; Hess, G.R. Distributary channels, sand lobes, and mesotopography of Navy Submarine Fan, California Borderland, with applications to ancient fan sediments. Sedimentology 1979, 26, 749-774. [CrossRef]

8. Stow, D.A.V. Deep-sea clastics: Where are we and where are we going? In Sedimentology: Recent Developments and Applied Aspects, 1st ed.; Brenchley, P.J., Williams, B.P.J., Eds.; Geological Society: London, UK, 1985; Volume 18, pp. 67-93. [CrossRef]

9. Stow, D.A.V. Deep clastic seas. In Sedimentary Environments: Processes, Facies and Stratigraphy, 3rd ed.; Reading, H.G., Ed.; Wiley-Blackwell: Oxford, UK, 1996; pp. 399-444.

10. Pickering, K.T.; Stow, D.A.V.; Watson, M.P.; Hiscott, R.N. Deep-water facies, processes and models: A review and classification scheme for modern and ancient sediments. Earth Sci. Rev. 1986, 23, 75-174. [CrossRef]

11. Pickering, K.T.; Hiscott, R.N.; Hein, F.J. Deep Marine Environments: Clastic Sedimentation and Tectonics, 1st ed.; Unwin Hyman: London, UK, 1989; 416p. [CrossRef]

12. Mutti, E.; Normark, W.R. Comparing Examples of Modern and Ancient Turbidite Systems: Problems and Concepts. In Marine Clastic Sedimentology: Concepts and Case Studies, 1st ed.; Leggett, J.K., Zuffa, G.G., Eds.; Springer: Dordrecht, The Netherlands, 1987; pp. 1-38. [CrossRef]

13. Mutti, E.; Normark, W.R. An Integrated Approach to the Study of Turbidite Systems. In Seismic Facies and Sedimentary Processes of Submarine Fans and Turbidite Systems, 1st ed.; Weimer, P., Link, M.H., Eds.; Springer: New York, NY, USA, 1991 ; pp. 75-106. [CrossRef]

14. Reading, H.G.; Richards, M. Turbidite Systems in Deep-Water Basin Margins Classified by Grain Size and Feeder System. Am. Assoc. Pet. Geol. Bull. 1994, 78, 792-822. [CrossRef]

15. Bouma, A.H. Key controls on the characteristics of turbidite systems. In Confined Turbidite Systems, 1st ed.; Lomas, S.A., Joesph, P., Eds.; Geological Society: London, UK, 2004; Volume 222, pp. 9-22. [CrossRef]

16. Prather, B.E. Controls on reservoir distribution, architecture and stratigraphic trapping in slope settings. Mar. Pet. Geol. 2003, 20, 529-545. [CrossRef]

17. Piper, D.J.W.; Normark, W.R. Sandy Fans-From Amazon to Hueneme and Beyond. AAPG Bull. 2001, 85, 1407-1438. [CrossRef]

18. Stow, D.A.V.; Mayall, M. Deep-water sedimentary systems: New models for the 21st century. Mar. Pet. Geol. 2000, 17, 125-135. [CrossRef]

19. Wagreich, M. Paleocene-Eocene paleogeography of the Northern Calcareous Alps (Gosau Group, Austria). In Paleogene of the Eastern Alps; Piller, W.E., Rasser, M.W., Eds.; Österr. Akad. Wiss., Schriftenr. Erdwiss. Komm 14: Vienna, Austria, 2001; pp. 57-75.

20. Wagreich, M. Subcrustal tectonic erosion in orogenic belts- A model for the Late Cretaceous subsidence of the Northern Calcareous Alps (Austria). Geology 1993, 21, 941-944. [CrossRef]

21. Wagreich, M. Subduction tectonic erosion and Late Cretaceous subsidence along the northern Austroalpine margin (Eastern Alps, Austria). Tectonophysics 1995, 242, 63-78. [CrossRef]

22. Egger, H.; Rögl, F.; Wagreich, M. Biostratigraphy and facies of Paleogene deep-water deposits at Gams (Gosau Group, Austria). Ann. Naturhist. Mus. Wien 2004, 106, 281-307.

23. Wagreich, M.; Faupl, P. Palaeogeography and geodynamic evolution of the Gosau Group of the Northern Calcareous Alps (Late Cretaceous, Eastern Alps, Austria). Palaeogeogr. Palaeoclimatol. Palaeoecol. 1994, 110, 235-254. [CrossRef]

24. Wagreich, M.; Kollmann, H.A.; Egger, H.; Grachev, A.F.; Summesberger, H. Excursion Guide to RECCCE Workshop. In Rapid Environmental/Climate Changes and Catastrophic Events in Late Cretaceous and Early Paleogene. RECCCE Workshop Abstracts and Excursion Guide; Wagreich, M., Ed.; Geologische Bundesanstalt: Vienna, Austria, 2009; Ber. d. Geol. B.-A.; Volume 78, pp. 49-63.

25. Wicher, C.A.; Bettenstaedt, F. Die Gosau-Schichten im Becken von Gams (Österreich) und die Foraminiferengliederung der höheren Oberkreide in der Tethys. PalZ Sonderh. Biostratigraphie Oberkreide 1956, 30, 87-136. [CrossRef]

26. Kollmann, H.A. Zur stratigraphischen Gliederung der Gosauschichten von Gams. Mitt. Ges. Geol. Bergbaustud. 1963, 13, 189-212.

27. Kollmann, H.A. Stratigraphie und Tektonik des des Gosaubeckens von Gams (Steiermark, Österreich). Jahrb. Der Geol. Bundesanst. 1964, 107, 71-159.

28. Summesberger, H.; Wagreich, M.; Bryda, G. Upper Maastrichtian cephalopods and the correlation to calcareous nannoplankton and planktic foraminifera zones in the Gams Basin (Gosau Group; Styria, Austria). Ann. Naturhist. Mus. Wien 2009, 111, 159-182. 
29. Egger, H.; Wagreich, M. Upper Paleocene-Lower Eocene nannofossils from the Gosau Group of Gams/Styria (Austria). In Paleogene of the Eastern Alps; Piller, W.E., Rasser, M.W., Eds.; Österr. Akad. Wiss., Schriftenr. Erdwiss. Komm 14: Vienna, Austria, 2001; pp. 465-472.

30. Stradner, H.; Eder, G.; Grass, F.; Lahodynsky, R.; Mauritsch, H.J.; Preisinger, A.; Rögl, F.; Surenian, R.; Zeissl, W.; Zobetz, E. New $\mathrm{K} / \mathrm{T}$ sites in the Gosau formation of Austria. Terra Cogn. 1987, 7, 7.

31. Lahodynsky, R. Geology of the K/T Boundary Site at Knappengraben Creek (Gams, Styria). In IGCP Project 199 "Rare Events in Geology": Abstracts of Lectures, Excursion Guide: Vienna, Austria, 12-17 September 1988; Ber. D. Geol. B.-A.: Vienna, Austria, 1988; Volume 15, pp. 33-36.

32. Preisinger, A.; Stradner, H. Excursion Guide to the Cretaceous/Tertiary boundary site at Knappengraben, Gams (Styria). In Proceedings of the Abstracts and Program for the 52nd Annual Meeting of the Meteoritical Society; Vienna, Austria, 31 July-4 August 1989, LPI Contribution: Vienna, Austria, 1989; 282p.

33. Egger, H.; Koeberl, C.; Wagreich, M.; Stradner, H. The Cretaceous-Paleogene (K/Pg) boundary at Gams, Austria: Nannoplankton stratigraphy and geochemistry of a bathyal northwestern Tethyan setting. Stratigraphy 2009, 6, 333-347.

34. Wagreich, M.; Egger, H.; Gebhardt, H.; Mohammed, O.; Spötl, C.; Koukal, V.; Hobiger, G. A new expanded record of the Paleocene-Eocene transition in the Gosau Group of Gams (Eastern Alps, Austria). Ann. Naturhist. Mus. Wien 2011, $113,35-65$.

35. Stradner, H.; Rögl, F. Microfauna and Nannoflora fo the Knappengraben Section (Austria) across the Cretaceous/Tertiary Boundary. In IGCP Project 199 "Rare Events in Geology": Abstracts of Lectures, Excursion Guide: Vienna, Austria 12-17 September 1988; Ber. d. Geol. B.-A.: Wien, Austria, 1988; Volume 15, pp. 25-26.

36. Krenmayr, H.G. Die Nierental-Formation der Oberen Gosau-Gruppe (Oberkreide-Paleozän, Nördliche Kalkalpen) in Berchtesgaden: Definition, Fazies und Environment. Jahrb. Der Geol. Bundesanst. 1999, 141, 409-447.

37. Punekar, J.; Keller, G.; Khozyem, H.M.; Adatte, T.; Font, E.; Spangenberg, J. A multi-proxy approach to decode the end-Cretaceous mass extinction. Palaeogeogr. Palaeoclimatol. Palaeoecol. 2016, 441, 116-136. [CrossRef]

38. Basemap.at. Available online: https:/ / basemap.at/ (accessed on 7 April 2017).

39. Sinclair, H.D.; Tomasso, M. Depositional evolution of confined turbidite basins. J. Sediment. Res. 2002, 72, 451-456. [CrossRef]

40. Normark, W.R.; Piper, D.J.W.; Hiscott, R.N. Sea level controls on the textural characteristics and depositional architecture of the Hueneme and associated submarine fan systems, Santa Monica Basin, California. Sedimentology 1998, 45, 53-70. [CrossRef]

41. Normark, W.R.; Piper, D.J.W.; Sliter, R. Sea-level and tectonic control of middle to late Pleistocene turbidite systems in Santa Monica Basin, offshore California. Sedimentology 2006, 53, 867-897. [CrossRef]

42. Romans, B.W.; Normark, W.R.; McGann, M.M.; Covault, J.A.; Graham, S.A. Coarse-grained sediment delivery and distribution in the Holocene Santa Monica Basin, California: Implications for evaluating source-to-sink flux at millennial time scales. Geol. Soc. Am. Bull. 2009, 121, 1394-1408. [CrossRef]

43. Covault, J.A.; Romans, B.W. Growth patterns of deep-sea fans revisited: Turbidite-system morphology in confined basins, examples from the California Borderland. Mar. Geol. 2009, 265, 51-66. [CrossRef]

44. Bown, P.R.; Young, J.R. Techiques. In Calcareous Nannofossil Biostratigraphy; Bown, P.R., Ed.; Kluwer Academic Publications: Dordrecht, The Netherlands, 1998; pp. 16-28.

45. Martini, E. Standard Tertiary and Quaternary Calcareous Nannoplankton Zonation. In Proceedings of the 2nd International Conference on Planktonic Microfossils, Roma, Italy, 23-28 September 1970; pp. 737-785.

46. Okada, H.; Bukry, D. Supplementary modification and introduction of code numbers to the low-latitude coccolith biostratigraphic zonation. Mar. Micropaleontol. 1980, 5, 321-325. [CrossRef]

47. Aubry, M.-P.; Salem, R. The Dababiya Core: A window into Paleocene to Early Eocene depositional history in Egypt based on coccolith stratigraphy. Newsl. Stratigr. 2012, 9, 287-346.

48. Agnini, C.; Fornaciari, E.; Raffi, I.; Catanzariti, R.; Pälike, H.; Backman, J.; Rio, D. Biozonation and Biochronology of Paleogene Calcareous Nannofossils from low and middle latitudes. Newsl. Stratigr. 2014, 47, 131-181. [CrossRef]

49. Boenigk, W. Schwermineralanalyse, 1st ed.; Enke: Stuttgart, Germany, 1983; 158p. [CrossRef]

50. Dickson, J.A.D. Carbonate identification and genesis as revealed by staining. J. Sediment. Petrol. 1966, 36, 491-505. [CrossRef]

51. Koukal, V. Paleogene Deep-Water Facies of the Upper Gosau Subgroup at Gams (Styria, Austria). Ph.D. Thesis, University of Vienna, Vienna, Austria, 2020.

52. Folk, R.L. Petrology of Sedimentary Rocks; Hemphill's: Austin, TX, USA, 1968.

53. Stern, G.; Wagreich, M. Provenance of the Upper Cretaceous to Eocene Gosau Group around and beneath the Vienna Basin (Austria and Slovakia). Swiss J. Geosci. 2013, 106, 505-527. [CrossRef]

54. Walker, R.G. Facies Models 8. Turbidites and Associated Coarse Clastic Deposits. In Facies Models; Walker, R.G., Ed.; Geological Association of Canada: St. John, NL, Canada, 1979; pp. 91-103. [CrossRef]

55. Faupl, P.; Wagreich, M. Late Jurassic to Eocene Palaeogeography and Geodynamic Evolution of the Eastern Alps. Mitt. Österr. Geol. Ges. 2000, 92, 79-94.

56. Woletz, G. Charakteristische Abfolgen der Schwermineralgehalte in Kreide- und Alttertiär-Schichten der nördlichen Ostalpen Jahrb. Geol. B.-A. 1963, 106, 89-119.

57. Hubert, J.F. A zircon-Tourmaline-Rutile maturity index and the interdependence of the composition of heavy mineral assemblages with the gross composition and texture of sandstones. J. Sediment. Petrol. 1962, 32, 440-450. [CrossRef] 
58. Garzanti, E.; Andò, S. Heavy mineral concentration in modern sands: Implications for Provenance Interpretation. In Heavy Minerals in Use; Mange, M.A., Wright, D.T., Eds.; Elsevier: Amsterdam, The Netherlands, 2007; Volume 58, pp. 517-545. [CrossRef]

59. Pober, E.; Faupl, P. The chemistry of detrital chromian spinels and its implications for the geodynamic evolution of the Eastern Alps. Geol. Rdsch. 1988, 77, 641-670. [CrossRef]

60. Mange, M.A.; Maurer, H.F.W. Heavy Minerals in Colour, 1st ed.; Springer: Dordrecht, The Netherlands, 1992. [CrossRef]

61. Garzanti, E.; Andò, S.; Vezzoli, G. The Continental Crust as a Source of Sand (Southern Alps Cross Section, Northern Italy). J. Geol. 2006, 114, 533-554. [CrossRef]

62. Garzanti, E.; Andò, S. Plate tectonics and heavy mineral suites of modern sands. In Heavy Minerals in Use; Mange, M.A., Wright, D.T., Eds.; Elsevier: Amsterdam, The Netherlands, 2007; Volume 58, pp. 741-763. [CrossRef]

63. Schuster, R. Das eo-Alpine Ereignis in den Ostalpen: Plattentektonische Situation und interne Struktur des Ostalpinen Kristallins. In Brenner Arbeitstagung 2003 Trins im Gschnitztal, 1-5 September 2003: Geologische Kartenblätter 1:50.000 148 Brenner, 175 Sterzing; Rockenschaub, M., Ed.; Geologische Bundesanstalt: Vienna, Austria, 2003; pp. 141-159.

64. Leeder, M.R. Sedimentology and Sedimentary Basins_From Turbulence to Tectonics, 2nd ed.; Wiley Blackwell: Oxford, UK, 2011; 768p.

65. Schmid, S.; Fügenschuh, B.; Kissling, E.; Schuster, R. Tectonic map and overall architecture of the Alpine orogeny. Eclogae Geol. Helv. 2004, 97, 93-117. [CrossRef]

66. Schuster, R.; Kurz, W.; Krenn, K.; Fritz, H. Introduction to the Geology of the Eastern Alps. Ber. Der Geol. Bundesanst. Wien 2013, 99, 121-133.

67. Missoni, S.; Gawlick, H.-J. Evidence for Jurassic subduction from the Northern Calcareous Alps (Berchtesgaden; Austroalpine, Germany). Int. J. Earth Sci. 2011, 100, 1605-1631. [CrossRef]

68. Missoni, S.; Gawlick, H.-J. Jurassic mountain building and Mesozoic-Cenozoic geodynamic evolution of the Northern Calcareous Alps as proven in the Berchtesgaden Alps (Germany). Facies 2011, 57, 137-186. [CrossRef]

69. Knierzinger, W.; Wagreich, M.; Palzer-Khomenko, M.; Gier, S.; Meszar, M.; Lee, E.; Koukal, V.; Strauss, P. Provenance and palaeogeographic evolution of Lower Miocene sediments in the eastern North Alpine Foreland Basin. Swiss J. Geosci. 2019, 112, 269-286. [CrossRef]

70. Wagreich, M. Sedimentologie und Beckenentwicklung des tieferen Abschnittes (Santon-Untercampan) der Gosauschichtgruppe von Gosau und Rußbach (Oberösterreich,-Salzburg). Jahrb. Der Geol. Bundesanst. 1988, 131, 663-685.

71. Pyles, D.R.; Syvitski, J.P.M.; Slatt, R.M. Defining the concept of stratigraphic grade and applying it to stratal (reservoir) architecture and evolution of the slope-to-basin profile: An outcrop perspective. Mar. Pet. Geol. 2011, 28, 675-697. [CrossRef]

72. Prather, B.E. Calibration and visualization of depositional process models for above-grade slopes: A case study from the Gulf of Mexico. Mar. Pet. Geol. 2000, 17, 619-638. [CrossRef]

73. Smith, R. Silled sub-basins to connected tortuous corridors: Sediment distribution systems on topographically complex subaqueous slopes. In Confined Turbidite Systems; Lomas, S.A., Joseph, P., Eds.; Geological Society Special Publications: London, UK, 2004; Volume 222, pp. 23-43. [CrossRef]

74. Faupl, P. Die Flyschfazies in der Gosau der Weyerer Bögen (Oberkreide, Nördliche Kalkalpen, Österreich). Jahrb. Der Geol. Bundesanst. 1983, 126, 219-244.

75. Wagreich, M. Stratigrafie und Lithofazies der Branderfleck-Formation und der Gosau-Gruppe (Oberkreide) von Lilienfeld (ÖK 56 St. Pölten). In Arbeitstagung 2013 der Geologischen Bundesanstalt Geologie der Kartenblätter 55 Ober-Grafendorf und 56 St. Pölten, Melk 23-27 September 2013: Wolfgang Schnabel zum 75. Geburtstag gewidmet; Gebhardt, H., Ed.; GBA: Vienna, Austria, 2013; pp. 20-37.

76. Normark, W.R.; Piper, D.J.W.; Romans, B.W.; Covault, J.A.; Dartnell, P.; Sliter, R.W. Submarine canyon and fan systems of the California Continental Borderland. In The Southern California Continental Borderland; Lee, H.J., Normark, W.R., Eds.; Geological Society of America: Boulder, CO, USA, 2009; Volume 454, pp. 141-168. [CrossRef]

77. Scheibner, C.; Speijer, R.P. Late Paleocene-early Eocene Tethyan carbonate platform evolution-A response to long- and short-term paleoclimatic change. Earth-Sci. Rev. 2008, 90, 71-102. [CrossRef]

78. Covault, J.A.; Graham, S.A. Submarine fans at all sea-level stands: Tectono-morphologic and climatic controls on terrigenous sediment delivery to the deep sea. Geology 2010, 38, 939-942. [CrossRef]

79. Wei, E.A.; Homes, J.J.; Driscoll, N.W. Strike-Slip Transpressional Uplift Offshore San Onofre, California Inhibits Sediment Delivery to the Deep Sea. Front. Earth Sci. 2020, 8, 51. [CrossRef] 